\title{
Riot in Mexico City: a challenge to the colonial order?
}

\author{
ARNAUD EXBALIN
}

École des Hautes Études Hispaniques et Ibériques, Casa de Velázquez, Madrid

\begin{abstract}
Obviously the city of Mexico is far away from Europe. Nevertheless, it was the perfect exemplar of city organized along imperial lines. As the capital of 'New Spain' and the headquarters of the viceroy and archbishop, it was the showcase of Spain in America. But suddenly and unexpectedly, the Spanish government's colonial policy had to be reconsidered on 8 June 1692 when the most important riot in the history of the city of Mexico broke out. A crowd of thousands of Indians gathered on the Plaza Mayor and kept shouting 'long live the king, but kill the government'. They lynched the National Guards and burned every sign and symbol related to Spain. Far from being a mere food riot, it was a genuine political movement. The riot of 8 June 1692 was the result of 'good government police' that is to say 'police' understood in its original sense as good government of the city. This article examines the consequences of the revolt for the city's police and for the Spanish colonial order which was based upon the separation of the Spanish and Indian population.
\end{abstract}

Riots and popular uprisings are favourite topics in ancien régime historiography. There is abundant research on their number, classification (agitations, riots, revolts, etc.), multiple origins, the identity and motivations of the agitators and their impact on political regimes. ${ }^{1}$ However, there are few studies specifically dedicated to the role and actions of the forces of control and any changes these events brought about in how law and order was practised in cities. ${ }^{2}$ As an example, Hispanists believe that the Esquilache riots in Madrid in March 1766 were the reason for the major police reforms drawn up by the count of Aranda the day after the uprising and put into practice in 1768. ${ }^{3}$ These created a new two-tiered administrative division (cuarteles and barrios) and a

${ }^{1}$ As the bibliography for this topic is huge, we will just mention two pioneering works: B. Porchnev, Les soulèvements populaires en France de 1623 à 1648 (Paris, 1963), and E.P. Thompson, The Making of the English Working Class (London, 1963). For a recent bibliographical overview, see J. Nicolas, La rébellion française. Mouvements populaires et conscience sociale (1661-1789) (Paris, 2002).

2 With the exception of A. Farge and J. Revel, Logiques de la foule. L'affaire des enlèvements d'enfants. Paris 1750 (Paris, 1988).

3 J.M. López García, El motín contra Esquilache (Madrid, 2006). 
new body of law enforcement officers for the capital, the alcaldes de barrio, numbering 64 men. In this case, the riot encouraged projects to 'modernize' the systems for controlling the population and hastened the implementation of new ways of maintaining everyday law and order: new territorial divisions and regular patrols by the alcaldes de barrio. What was the situation in the cities of the Spanish empire, in particular the most prestigious and populated city in 'the Indies', Mexico City, the capital of New Spain, which on 8 June 1692 experienced the largest riot in its history?

In Mexico City, urban law and order was the product of military conquest: the capital of the Aztec empire fell into the hands of Hernán Cortés and his troops in 1521. After the Spanish city was established (1521-40) on the ruins of Tenochtitlan, the idea of separating the Indians for their protection and conversion, developed by the clergy and taken up by the crown, was realized by the creation of two 'republics'. The república de españoles was represented by the parish of the cathedral and the traza, the city laid out on a grid pattern. It was governed by the viceroy, the archbishop, the municipal council and several courts, including the royal Audiencia. The república de indios, organized within the parcialidades on the outskirts of the city, had its own system of urban organization with municipal councils led by the Aztec nobility and the clergy, who indoctrinated the Indians in the barrios, the neighbourhoods reserved for the indigenous population, where they were obliged to live.

The riot of 8 June 1692 in Mexico City is often presented in the archives as the tumulto de los indios, the 'Indian tumult'. ${ }^{4}$ This expression calls for some preliminary remarks. The term 'tumult' has a pejorative connotation (noisy commotion, fruitless agitation), which indicates the desire of the authorities to downplay the political demands of the rioters. We will see, however, that such demands were certainly present, even if they were not formally expressed. The uprising of 8 June 1692 cannot in fact be reduced to a simple question of food, even though it had some of the features of a market riot. As Edward Thompson has clearly shown in relation to eighteenth-century England, cases of unrest, popular agitation and riots were not simply motivated by hunger. On the contrary, they were connected to a 'moral economy' where grain was considered by the lower social classes to be a common good. As a result, we will describe the uprising of 8 June 1692 as a 'riot'. ${ }^{5}$ In addition, the Indians were not the only group who revolted; there were also mestizos and poor whites among the rioters, in particular the small vendors of the Baratillo, a vast open-air

4 Among the 40 or so reports sent to the king and viceroy in 1692, tumulto is the most consistently recurring term.

${ }^{5}$ E.P. Thompson, 'The moral economy of the English crowd in the eighteenth century', Past E Present, 50 (1971), 76-136. 
market on the Plaza Mayor. ${ }^{6}$ The tumulto de los indios was actually a riot of a mixed plebeian class.

Everything began in the style of a classic ancien régime grain crisis. Due to episodes of hail and heavy rains, the land in the Valley of Mexico had not produced enough grain to supply the capital. The riots broke out, as often happens, during a religious festival, the celebration of the Corpus Christi. Thousands of rioting Indians in the Plaza Mayor shouted 'Long live the king, and death to bad government!', lynched the halberdiers of the palace guard and stoned the façade of the viceregal palace before setting it alight, also setting fire to other symbols of power: the gallows, the prison and the town hall. The authorities attributed this uprising to the drunkenness of the rioters, who were supposed to have consumed large quantities of pulque, and the poor morals of the plebeian class who permanently occupied the Baratillo. ${ }^{7}$ It had the following features: a marked ethnic dimension (the majority of the rioters were Indian and mestizo), a short duration (one evening, from $5 \mathrm{pm}$ to $9 \mathrm{pm}$ ), unprecedented violence (fires that ravaged half the buildings in the Plaza Mayor) and a lack of response from the authorities, at least in the first instance.

The Mexican riot of 8 June 1692 has been the subject of several studies thanks to the existence of abundant documentation. We have access to direct eye-witness accounts (in particular those of Carlos Sigüenza y Góngora and Antonio de Robles, who will serve as our guides here), reports sent to the viceroy and the king and the documents from the trial of the rioters. ${ }^{8}$ In an old article, Rosa Feijóo adopted a classical approach by examining the different causes and effects of the uprising. More recently, Thomas Calvo placed the riot in the context of similar incidents taking

${ }^{6}$ Descended from the pre-Hispanic tianguis, the Baratillo initially occurred weekly before becoming permanent during the course of the seventeenth century. They attracted a great deal of attention from the conquistadors, starting with Hernán Cortés, who gave a magnificent description of them when visiting Tlatelolco. On this market and its disturbances, see J. Olvera Ramos, Los mercados de la Plaza Mayor en la Ciudad de México (Mexico City, 2007).

7 Pulque is a typically Mesoamerican drink. It is a sort of beer based on the fermented juice of the agave plant, very commonly found on the central plateau of Mexico.

8 A. de Robles, Diario de sucesos notables (1665-96), ed. Antonio Castro Real (Mexico City, 1979), vol. II, 250-7, and Carlos Sigüenza y Góngora, 'Alboroto y motín de los Indios de México', in W. Bryant (ed.), Seis obras (Caracas, 1984), 95-141. These two authors were eye-witnesses of the riot. We know almost nothing about Antonio de Robles, except that he was the priest of a parish in Durango and he was in Mexico City at the time of the riot in order to receive treatment at the hospital of the Congregation of San Pedro. His account seems reliable while also being very critical of the authorities, in particular the viceroy. We know more about Carlos Sigüenza y Góngora: a former Jesuit, a respected scholar among the elites, cosmographer to the king and head chaplain of the Real del Amor de Dios hospital. He was a direct witness of the events he described and was at the forefront of the effort to rescue the palace archives. His account is the most complete one we have, but it contains a number of distortions and shows itself to be overly sympathetic to the viceroy. The handwritten documents are held by the Archivo General de Indias (AGI) in Seville, and the Archivo General de la Nación (AGN) and Archivo Histórico del Distrito Federal (AHDF) in Mexico City. 
place at the same time in Guadalajara and Tlaxcala. Finally, in a voluminous work that was her doctoral thesis, Natalia Silva Prada offered a detailed study of the revolt of 8 June 1692 through the prism of the history of the political culture. ${ }^{9}$ For our part, we will approach this major event in the history of Mexico City strictly from a 'policing' angle, an angle that has been highlighted on many occasions by analysts of urban riots but which is rarely used as the main analytical grid. ${ }^{10}$ We will treat the riot as a privileged vantage point for observing the workings of the city's administration and the action of the forces of law and order. On the one hand, the riot was the product of weaknesses in the government of the city, starting with the supply of grain. In this sense, it appears as a marker of 'bad government', an expression that refers to problems with policing. On the other hand, once the riot subsided, it shed light on the arrangements put in place by the urban authorities to restore law and order. We will thus attempt in this article to measure the impact of the trauma of 8 June 1692 on the law and order landscape of an imperial capital: Mexico City.

\section{The riot as the expression of an urban government in crisis}

One of the contributions of the research into the revolts under the ancien régime has been to show that episodes of crowd unrest were more than simple outbreaks of anger and can be treated as forms of political expression. ${ }^{11}$ With this in mind, we have mapped out the acts of violence committed by the rioters in order to identify those responsible for the public condemnation and 'bad government'. Reading the accounts of Carlos Sigüenza y Góngora and Antonio de Robles, both present during the incident, the urban space appears as a tool of expression for the rioters, Plaza Mayor functioning as a sort of resonance chamber for the demands

${ }^{9}$ R. Feijóo, 'El tumulto de 1692', Historia Mexicana, 14 [(56)] (1965), 656-79; T. Calvo, 'MexicoGuadalajara-Tlaxcala: la semaine des pierres (8-14 juin 1692)', in L. Croq (ed.), Le prince, la ville et le bourgeois (Paris, 2004), 81-107; Natalia Silva Prada, La política de una rebelión. Los indigenas frente al tumulto de 1692 en la ciudad de México (Mexico City, 2007).

10 It should be noted that at this point, the 'police' in its modern sense did not yet exist as a centralized authority with permanent personnel. When the term is used in the Spanish colonial archives (policia), it refers to an ideal of urban civilization based on the good governance of the city, the good manners of the townspeople and the conversion of native Americans to Christianity. See R. Hernández Franyuti, 'Historia y significados de la palabra policía en el quehacer político de la ciudad de México', Ulúa. Revista de historia, sociedad y cultura, 5 (July 2005), 9-34.

11 Natalie Zemon Davis has thus undertaken an analysis of the 'rites of violence'. In the case of the 1692 riot, Thomas Calvo evokes 'the language of stones'; Natalia Silva Prada insists for her part on the shouts made during the commotion: insults, demands and calls to sedition. N. Zemon Davis, Les cultures du peuple: rituels, savoirs et résistances au XVI siècle (Paris, 1979); Calvo, 'Mexico-Guadalajara-Tlaxcala', 103; Silva Prada, La política de una rebelión, 411-23. 


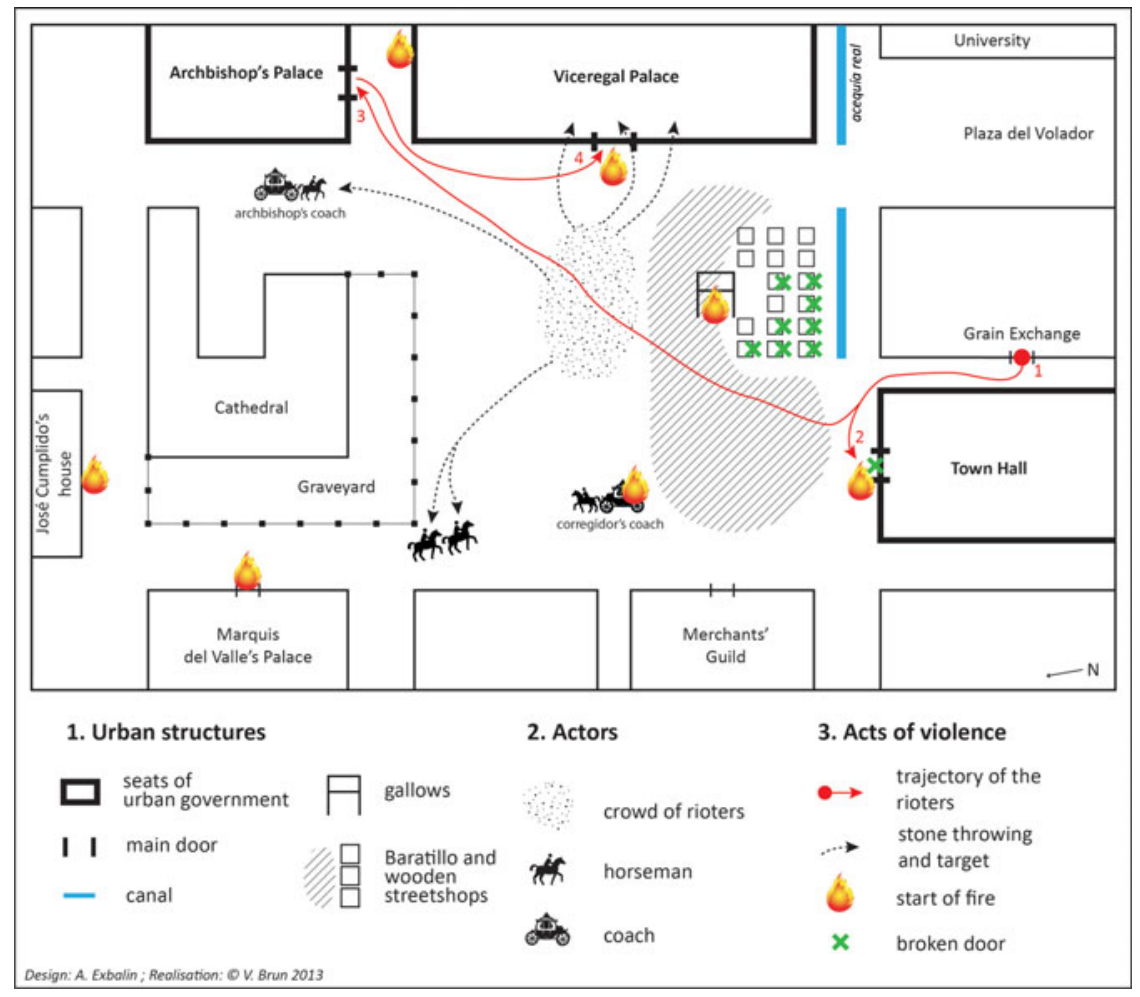

Figure 1: (Colour online) The geography of the acts of violence on the evening of 8 June 1692

Source: Sigüenza y Góngora, 'Alboroto y motín de los Indios de México'; Robles, Diario de sucesos notables; Silva Prada, La política de una rebelión.

of the people. As such, the violent actions of the crowd can be read as a demand for improved policing.

Figure 1 allows us to pinpoint the urban structures that make up the Plaza Mayor (seats of government, shops, gallows) and plot the trajectory of the rioters, the targets of the stone throwing and the starting points of the acts of arson, which together represent a statement in our view.

The trajectory of the rioters indicates that several authorities were sought out before the explosion of violence occurred, indicating a desire to find people to speak with. The spark that set off the chain of events was an incident that took place in the alhóndiga (grain exchange) at around 4 $\mathrm{pm}$. There was a shortage of corn, the staple food of the indigenous population, and the Indians jostled to get the last handfuls. One of them, a pregnant woman, fainted and died. Following this incident, the crowd, carrying the body of the dead woman, headed towards the town 
hall to hold the corregidor to account. ${ }^{12}$ The corregidor, however, had mysteriously disappeared. The group then unleashed its anger on the entrance door, which was broken down, and the rioters gained entry to the corregidor's apartments, which they ransacked. They then went to the archbishop's palace located on the other side of the plaza. This door was too well guarded by the armed family of the prelate to be broken down or vandalized and it was ultimately spared from the anger of the rebels. The crowd then marched towards the main door of the viceregal palace and was stopped twice from proceeding by the halberdiers, but the viceroy was absent at the time, attending a mass at the Convent of San Francisco. It was only when the door was closed again by the guards that it became the starting point of the fire that reduced the palace to ashes. This trajectory in a way outlines the hierarchy of the authorities in charge of the administration of the capital: the municipal authority headed by the corregidor, the power of the church represented by the archbishop and royal power embodied by the viceroy. It is precisely because the authorities did not agree to the rioters' demands, however, that the violence moved up a level.

The dotted-line arrows on the figure represent the stones thrown from the centre of the plaza, where the crowd of rioters were located, towards the periphery. Here as well, the order of the attacks is significant. According to Carlos Sigüenza y Góngora, the first target was the main balcony of the palace, which was in the middle of the building and marked the apartments of the vicereine. ${ }^{13}$ The balcony was customarily used by viceroys to celebrate royal occasions, such as the opening of the corridas, and to announce major events of the realm, such as the jubilees of births, marriages or funerals of members of the royal family. For the viceroy, the king's alter ego in the Indies, it was a sort of substitute throne. There were many other stones thrown during the riot, and they often reached their mark, for example the archbishop's coachman, who made a tentative appearance in the plaza, or the noblemen on horseback who attempted an avenging sortie which resulted in them being severely injured. ${ }^{14}$

Identifying the starting points of the fires gives an even more precise indication of who was being held to account. Fire, the traditional weapon of the people but also an old siege technique, has in the first place a purifying dimension. It was common at that time during popular commotions for rebels to burn an effigy (a painting or puppet) of the accused, as was the case in Madrid in March 1766 when a portrait of the minister Esquilache

12 A senior magistrate appointed by the king to oversee the city council. The first corregidor was appointed in 1574. He presided over the appointment of the municipal police. He was in particular the guarantor of plenty: grain, meat and drinking water supplies.

13 Sigüenza y Góngora, 'Alboroto y motín de los Indios de México', 125.

14 Robles, Diario de sucesos notables, 257. 
was burned in the Plaza Mayor. ${ }^{15}$ In Mexico City, there was no effigy, but there were buildings, street furniture and vehicles. The first thing that was burned was the corregidor's coach. Frustrated and furious at not being able to speak with the corregidor, the rioters 'went down into the coach yard, took out his coach and set it alight'. ${ }^{16}$ The rebels went so far as to slit the throats of the corregidor's mules, as if for a blood sacrifice. After the corregidor's coach, 'the first thing they set alight was the royal arms beneath the palace balcony, the royal apartments, those of the town hall and the gallows' ${ }^{17}$ There were also accounts of fires being started at the doors of the Casa del Marquis del Valle, the Casa de la Moneda and the house of Lieutenant José Cumplido. All of these arson sites are significant and indirectly name those held responsible for the people's wrath: Juan Núñez de Villavicencio, the city's corregidor since 1686, Gaspar de la Cerda Sandoval, Silva y Mendoza, Conde de Galve, viceroy since 1688, José Cumplido, Alguacil de Guerra (military commander) and keeper of the octroi levies. In the eyes of the rebels, all three were responsible for the bad government.

To understand better this explosion of violence, we need to place the government of the Conde de Galve (1688-96) within the context of the overall evolution of the Catholic monarchy. The viceroy continued the policy of fiscal austerity initiated by his predecessors. This involved, on the one hand, increasing royal tax revenues to restore the lustre of the crown, which had lost some of its shine: Madrid was counting on the Indies to regain its lost hegemony. On the other hand, they had to strengthen the system for defending the Carrera de Indias - the maritime route for carrying American silver between the Indies and Seville - which had been regularly attacked by English and French pirates since the beginning of the seventeenth century. The Conde de Galve thus increased the manpower of the Armada de Barlovento and improved the defence system of the fortified ports, which resulted in a significant increase in military expenditure. This expenditure, which made up almost 70 per cent of the viceregal budget, was essentially paid for by Mexico City. This meant tightening up collections from tributary populations. Thus in 1691, the priests of the Spanish parishes were ordered to conduct a vast census with the aim of flushing out Indians living in the Spanish city who had escaped paying tribute.

15 The 1692 riot needs to be compared with other urban riots. For Naples, see A. Hugon, Naples insurgée. De l'événement à la mémoire, 1647-1648 (Rennes, 2012); for Madrid, see López García, El motín contra Esquilache.

16 Declaration of the magistrate of the Juan de Escalante y Mendoza hearing recorded on 10 June 1692, AGI, Patronato 226, r. 2, i. 21.

17 Account of the captain of the company of palace guards, Manuel Torres, letter sent to the king, 10 Aug. 1692, G. García, Documentos inéditos o muy raros para la historia de México (Mexico City, 1982), 374. 
Beyond this imperial policy dictated by the crown, the crowd indirectly was accusing the viceroy and his 'accomplices' of clientelism and corruption: first illegal trading with Peru for personal gain, and secondly of imposing undue taxes and excessive inspections at the octroi boundary gatehouse on the poor mule drivers bringing supplies into Mexico City and the women selling pulque. In other words, the viceroy and his clientele were accused of disrupting the delicate balance of power between a 'pactist' monarchy and a guild-based society. ${ }^{18}$ The rights of the different guilds were jeopardized and the freedoms of the small vendors of the Baratillo ignored and flouted. As soon as he took up his position, the Conde de Galve banned the sale of pulque, although it was allowed in small quantities for elderly indigenous women. Next, he attempted to get rid of the Baratillo, because of the disorderliness caused by the occupation of Plaza Mayor. Even more seriously, during the grain shortage he committed the double error of decreeing the 'liberty of commerce' of grain and buying grain out of his own pocket to improve the city's supply, which could have been perceived as a form of speculation.

In summary, the riot of 8 June 1692 is more than a simple illustration of the urban crisis; it presents a model of the dysfunctions in the city's administration. The grain crisis and the rise in grain prices were certainly triggering factors, but beyond that, this classic food riot came to crystallize everything that was wrong with the city: the problems in the supply system, the corruption of the highest authorities, the abuse of power. The

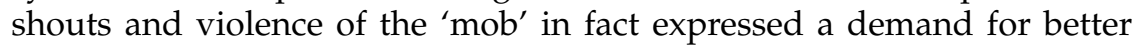
policing: respect of the freedoms granted to small vendors, assurance of plentiful supplies, maintenance of a society based on horizontal relationships between different bodies. Conversely, for the authorities the riot was the explosive product of a lack of civility among the plebeian class, especially the Indians from the barrios who overran the central areas of the Spanish city, got drunk on pulque and infected the Plaza Mayor with their bad manners, when the plaza was supposed to embody royal authority. The revolting Indians and mestizos had no respect and were incapable of staying in their place.

Examining the 1692 riot highlights the specifically colonial features of urban crisis in the cities of Spanish America. The physical absence of the sovereign and the distance from Madrid gave the local authorities (the viceroy and corregidor) a great deal of autonomy. This translated into abuses of power, corrupt practices and irregularities in the administration of the city, which were probably more pronounced in these remote territories than in Spain. In addition, there is the configuration of the town around a central plaza, notably different from Spanish plazas, which were only used for parades and bullfighting. It brought together the seats of

18 On this point, Annick Lempérière is an exception. A. Lempérière, Entre Dieu et le Roi, la République. Mexico, XVI $-X I X^{e}$ siècles (Paris, 2004). 
authority (the church, the viceroy's palace, the town hall, the Merchants' Guild), the market and the public exercise of justice, which entailed clear conflicts of use. It was in fact this exceptional concentration of activities and powers in the one space that made its management especially sensitive when the grain crisis occurred. The riot highlighted in particular the archaic nature of the separation between the two 'Republics'. This segregation, at the foundation of colonial urban order, was obviously no longer tenable in a city where everything was intermingled, where the Indian population lived in the heart of the traza and the Spanish were buying land in the parcialidades. The emergence of a colonial society with its hybridity and multiple forms of cultural exchange threatened the Spanish model of being a civilizing force. While the 1692 riot shed light on the demands of the plebeian class, it also brought to light the shortcomings of the forces of law and order in the capital, a point we should now examine.

\section{The weakness of the forces of law and order}

The riot is a privileged vantage point for observing the forces of law and order in action. The extent of the damage in Mexico City is explained by the weakness of the single company of guards responsible for law and order in the capital: the halberdiers of the viceroy's palace.

This is the picture painted by Sigüenza y Góngora of the soldiers of the palace guard after the onslaught of the insurgents: 'two or three were seriously wounded, another had his wrist broken following the explosion of a musket and the rest of the company had been pelted head to foot with stones' ${ }^{19}$ For another witness, the priest Antonio de Robles, the halberdiers were incapable of repelling the attack of the rioters: the captain lost his shield and the guards had to take refuge in the palace, 'without offering any form of resistance except closing the doors' ${ }^{20}$ In the panic, two soldiers were left outside to the mercy of the rebels; they were stoned, then lynched. As for the captain, he forgot his halberd outside the palace, which became the very weapon used - as Sigüenza y Góngora enjoys pointing out to set fire to the 'great and magnificent balcony of the vicereine'. Both of our witnesses put great stress in their accounts on the total lack of preparation and training of the soldiers. They report that the musketeers on the palace terrace lacked gunpowder and ball. Only 30 or so shots were said to be fired and they had trouble hitting their mark, only serving, at best, to injure and kill a few rebels. Both Robles and Sigüenza y Góngora especially enjoyed describing the provocative gestures the rioters made at the soldiers: a mulatto shook his cape at them like a bullfighter, an

${ }^{19}$ Sigüenza y Góngora, 'Alboroto y motín de los Indios de México', 124: 'dos o tres estaban muy heridos, otro quebrada la mano izquierda por haber revendato una tercerola, y los restantes apedrados de pies a cabeza'.

${ }^{20}$ Robles, Diario de sucesos notables, 250: 'sin tener forma de otra resistencia que la de cerrar las puertas'. 
Indian danced the tocotín (a sacred pre-Hispanic dance) and insults flew on all sides in Nahuatl and in Spanish: 'Shoot! Shoot! ... and if you have no musket ball, send down tomatoes!'21

It is remarkable that the only attempt to contain the rioters' rage came from members of the church. The first attempt was made by the treasurer of the cathedral, a priest of an indigenous parish: accompanied by three novices and a Franciscan, he led an improvised Holy Communion procession from the cathedral. According to Robles, this effort was productive as some of the crowd joined the cortege, asked for penance and mercy and extinguished several fires. The second initiative came from the cantor of the cathedral, who started to preach in Nahuatl to calm the fervour of his flock, 'exhorting them to peace and calm and asking them to go back to their homes, which they did'. ${ }^{22}$ Where the guards were incapable of gaining control, the threat of divine wrath and the use of the vernacular seemed to have been much more effective. This episode is evidence of the primacy of the government of souls over physical force. The clerics - Franciscans and Jesuits - and the priests of indigenous parishes were effectively the first defenders and protectors of the Indian population against the civil authorities and it is revealing that it never occurred to the rioters to set fire to the cathedral.

The uprising exposed the shortcomings, or indeed the ineffectuality, of the armed forces in the capital of New Spain, but this weakness in the forces of control was not specific to Mexico City. It is one of the features of colonial towns in America. ${ }^{23}$ Moreover, what system could have resisted such an outpouring of violence? Accounts of other urban revolts show the limits of anti-rioting provisions in the towns of the ancien régime. In Madrid in 1766, the company of Walloon soldiers was targeted and almost 20 died from their ranks. ${ }^{24}$ The situation of Mexico City, an open city without walls or an army, is so unique it is worth dwelling on. Mexico City's Plaza Mayor, like the majority of central plazas in Ibero-American towns and unlike the plazas mayores on the Iberian Peninsula, was an open square. It was served by four wide avenues and a canal that connected the plaza to Lake Texcoco. The plaza was also enormous: it measured almost 200 metres north-south and 240 metres east-west, almost double that of its counterpart in Madrid. This exaggerated size was of course deliberate on the part of the city founders, Hernán Cortés in particular, but it presented a double disadvantage when it came to maintaining law and order. First, it made it a fundamentally attractive space for crowds, which is the case

${ }^{21}$ Sigüenza y Góngora, 'Alboroto y motín de los Indios de México', 122: ‘ - ¡Tirad, tirad! -, les decían a los soldados, - iy si no traéis pelotas, echad tomates!'

22 Robles, Diario de sucesos notables, 251.

${ }^{23}$ R.L. Kagan, 'A world without walls: city and town in colonial Spanish America', in J.D. Tracy (ed.), City Walls: The Urban Enceinte in Global Perspective (Cambridge, 2000), 117-52.

24 The Walloon Guard effectively crystallized the hatred of foreignness. See López García, El motín contra Esquilache, 114. 
to this day. Secondly, as a space open on all four sides it was particularly vulnerable in the event of a riot, especially with regards to the armed forces present in the city at that time.

Unlike Madrid, which had a regular army housed in barracks from the beginning of the eighteenth century, Mexico City did not have armed forces until the beginning of the $1760 \mathrm{~s} .{ }^{25}$ Prior to this date, the city appeared medieval in style, as its defence still involved the obligation of the Spanish to take part in the military reviews organized by the viceroy, the head of the army. After the conquest, however, once the pacification period was over, this practice seems to have fallen into disuse. Only the Merchants' Guild (consulado) and a few trade guilds had militias, which mainly played an honorific role during religious festivals and public ceremonies. ${ }^{26}$ Finally, the use of military power was the responsibility of the miles, namely the noble Spanish knights who were part of the court of the viceroy and belonged to the prestigious orders of Santiago and Calatrava, military orders born out of the Reconquista. We know, however, that only two members of these orders attempted a sortie during the uprising: the first lost consciousness after being hit on the head by a stone and the second was spitting blood after receiving a stone full in the chest. ${ }^{27}$ All evidence suggests that these knights were not prepared or equipped to confront an angry crowd.

The palace guard was in fact the only permanent military force in the city at the end of the seventeenth century. It was made up of around 100 recruits (soldiers, auxiliaries, a sergeant and a captain) who lived on site at the palace, which had a barracks and an armory. There were thus 100 men in total who took turns to stand guard. How many of them were there on the evening of the riot? Out of the 40 usually on guard, Robles counted only 9. The guards themselves claimed they numbered around 20. That was quite clearly not enough to defend such a vast building, especially since the company's halberdiers were, it seems, hardly quick to fight. They had a poor reputation and the same Robles described their barracks as a veritable den of iniquity, ${ }^{28}$ they spent most of their time playing cards or making bladed weapons for resale on the Baratillo.

The violence of the events turns a light on the vacuum in the city's government. For more than four hours, no authority came forward and the handful of palace guards were a sorry sight. By around $9 \mathrm{pm}$, there was nothing left to set alight and the last shops had been looted. The rioters

${ }^{25}$ M. del Carmen Velázquez, El estado de guerra en Nueva España (1760-1808) (Mexico City, 1997).

26 The militia also had the duty of patrolling the streets at night during festivals. On that date, only the militia of the silversmith's guild, created in 1686, was operating. See G. Antonio Salas, 'La organización del ejército en Nueva España', Boletín del Archivo General de la Nación, 12 (1940), 661.

27 Robles, Diario de sucesos notables, 254.

28 Ibid., 258. 
retreated and then came the phase of repression. To what extent did this return to order imply an overhaul (or not) of the city's administration and above all the forces of law and order?

\section{Restoring order}

Among the solutions used to restore law and order in the capital, we can distinguish the immediate measures to pacify and control the plebeian population from the medium-term measures aimed at creating lasting social peace.

In the first category, it is no surprise to find the organization of a triumphal tour of the city carried out the day after the riot by the viceroy, the archbishop, the magistrates of the Real Audiencia, the city councillors and the noblemen on horseback. ${ }^{29}$ The aim of this parade in gala attire was to mend the social body that was undone during the uprising, by giving the illusion of a united community standing together.

In the afternoon of 9 June, the viceroy staged a military review that was quite medieval in style. Several hundred Spanish criollos (merchants, master tradesmen) were present, but some did not even carry arms. Next, the viceroy formed two cavalry units: the first was drawn from the mason's guild, the second from volunteers. These militiamen were enlisted and paid from the funds of the crown (Real Hacienda) ${ }^{30}$ the beginnings of a sort of permanent troop thus took shape. In addition to these two cavalry units, the viceroy created two companies of black and mulatto militiamen and reformed his personal guard of halberdiers, beginning with the dismissal of its captain.

Once formed, these improvised forces under the command of the viceroy were distributed over the various strategic points of the city (the palace, patrols in the parcialidades, bridges, gatehouses of the octroi zone). The city was under lockdown for almost a month. At the same time, the forces of repression were unleashed: suspects were arrested at the city's exits, in their houses and in their neighbourhoods, including in the hospitals. ${ }^{31}$ They were apprehended because stolen clothes from the Baratillo were found in their homes (without it being certain if they were themselves the looters) or because Spanish witnesses supposedly saw them at the heart of the action on the night of the riot. The judicial investigation was launched on 11 June and the trial that followed was summary: in less than

${ }^{29}$ Ibid., 257, and Sigüenza y Góngora, 'Alboroto y motín de los Indios de México', 133.

30 This information and that which follows are drawn from the accounts of Antonio de Robles and Carlos de Sigüenza y Góngora and from Rosa Feijóo's study as well as from a dossier from the AHDF, Historia en General, vol. 1, dossier 1.

31 Thomas Calvo has closely examined the legal repression of the rioters in two articles: 'Mexico-Guadalajara-Tlaxcala', and 'Soberano, plebe y cadalso bajo una misma luz en Nueva España', in P. Gonzalbo Aizpuru (ed.), Historia de la vida cotidiana en México (Mexico City, 2005), vol. III, 287-322. 
20 days, 80 rioters were arrested and judged in the criminal chamber of the Audiencia. Three-quarters of these were native American men and women. The sentences were heavy: 12 were sentenced to death (after which the bodies were mutilated and displayed), 32 were sentenced to forced labour and flogging and 9 punished by flogging alone. ${ }^{32}$ For several weeks, the hangman's ropes stretched tight and the axe of the executioner removed hands and heads. The whole city was terrified.

Over the longer term, restoring the colonial order meant regaining control of a city that was disturbed by the intermingling of cultures and the uncontrolled movement of individuals. This implied the revival and enforcement of urban regulations that had been diluted by the laxity of magistrates and constantly violated by the greed of landlords. After taking on the roles of viceroy-warrior and viceroy-chief justice, the Conde de Galve assembled secretaries, printers and public criers to issue a battery of prohibitive regulations directed at the Indians: a ban on assemblies of more than four people, a ban on wandering the streets after nightfall, a ban on the sale of pulque, and the permanent closure of the Baratillo. ${ }^{33}$

We saw that the prohibition of pulque and the banning of the Baratillo were among the causes of the riot. Would not the application of these regulations, along with excessively harsh penalties for offenders, generate new tensions? Antonio de Robles did not hesitate to criticize a set of regulations he saw as absurd, each edict being 'worse than the previous one, contrary and prejudicial to the peace'. ${ }^{34}$ On 19 July, the production and sale of pulque were definitively prohibited in all of New Spain, ${ }^{35}$ but already by 31 July the prohibition was relaxed and the sale of medicinal pulque (pure, white, without any root) was once again tolerated. ${ }^{36}$ The prohibition could not in effect continue without having an adverse effect on royal tax revenue, which earned considerable profits from it. Following a report made by the physicians of the Protomedicato tribunal that outlined the medicinal virtues of white pulque and the necessities of funding the Armada de Barlovento, the production, sale and consumption of pulque were once again made legal in June $1697 .{ }^{37}$

Among the series of ordinances enacted in July-August 1692 by the viceroy, two regulations are of special interest, because they suggest that

32 On the functioning of the judicial system under the ancien régime and the application of corporal punishment in Europe, see M. Porret, Becarria, le droit de punir (Paris, 2003), and P. Bastien, L'exécution publique à Paris au XVIII e siècle. Une histoire des rituels judiciaires (Paris, 2006).

33 Feijóo, 'El tumulto de 1692', 672-8.

34 Robles, Diario de sucesos notables, 257: 'Echáronse diversos bandos, unos peores que otros, contrarios y perjuiciales a la paz.'

35 Real Certificates dated 11 Feb. and 7 Jul. 1693: 'Reiteró la orden y la ley de nuevo al corregidor de esta ciudad para que atienda y cele con vigilante cuidado y como es de su obligación la prohibición de la bebida', AHDF, Pulquerías, vol. 3719, dossier 1, 4 f. (1693).

${ }^{36}$ Robles, Diario de sucesos notables, 264-5. White pulque derived from the fermentation of agave nectar is distinguished from yellow pulque mixed with roots with mind-altering properties.

37 AHDF, Pulquerías, vol. 3719, dossier 2 (1697). 
good government in Mexico City relied on the restoration of an original order that came out of the conquest and the foundation of the city.

The laws forbidding Indians from wearing Spanish clothing and forcing them to reside in their own zones showed the extent to which the revival of ethnic barriers, formulated more than a century and a half earlier, was one of the privileged levers in the process of restoring law and order. ${ }^{38}$ Once again, this raises the question of their actual application. The prohibition against wearing Spanish hose or capes for example implies a very careful examination by the judges and their alguacils of the arrested individual, because in a highly mixed society, skin colour and physical traits were no longer adequate to define 'Indianness'. Not to mention the fact that in the vast melting pot of hybridization that a colonial city represents, it was relatively simple to take advantage of the confusions concerning identity and mimic the mestizo, if only by speaking in Spanish. There were abundant cases of impersonation. This legislation may in the end have been intended to satisfy the members of the Council of the Indies, which it was expedient to reassure.

Was it any more feasible to exclude Indians from the Spanish city? This was effectively a restrictive measure that implied the displacement of several hundred families from the centre of the city to the periphery. For the owners of the rental apartment buildings where the Indians lived, it also represented a loss to be recovered. Finally, it ran the risk of driving away the domestic staff who had become invaluable to the upper-class families. On the other hand, it was potentially profitable for the royal tax office, which could collect tributes more easily. It was also something the priests of indigenous parishes had been demanding for a long time, complaining that they were unable to administer their religion properly. This large-scale operation began with the redefinition of the limits of the traza, a task entrusted to Sigüenza y Góngora, who justified his plans with reference to the first chroniclers of Mexico City (Antonio de Herrera and Juan de Torquemada). ${ }^{39}$ In his opinion, it was necessary to exclude the Indians from the centre of the city and lodge the Spanish population in the heart of the traza. Sigüenza y Góngora thus painstakingly examined the first plans of Mexico City and made several trips around the city in order to redefine and set the limits of the Spanish zone. For their part, the Franciscans sent reports to the viceroy in which they expressed their wish for the 'Indians to be contained in their districts', to help them administer the Christian doctrine (mass, sacraments, rituals) more effectively. ${ }^{40}$

38 Real Acuerdo dated 21 Jun. 1692, AGN, Historia, vol. 413, fol. 1.

${ }^{39}$ Letter from Carlos Sigüenza y Góngora to the viceroy dated 5 Jul. 1692, retranscribed in E. O'Gorman, 'Sobre los inconvenientes de vivir los indios en el centro de la ciudad', Boletín del Archivo General de la Nación, 9 (1938), 4.

40 This quote is from the letters sent by the Franciscans to the viceroy, available for consultation in the above-cited dossier, 12. 
The second step was to communicate the information to both the Indian and Spanish populations, the dissemination of the edict being the condition sine qua non of its success. The Indians had 20 days to leave the area and set up their homes outside the traza, under pain of receiving 200 lashes and six years of hard labour. This ordinance applied to all Indians, including domestics and porters. Only apprentices working in the bakeries and those sentenced to hard labour were allowed to remain. Conversely, the Spanish were forbidden to admit Indians into their houses (as domestics), under pain of receiving a 100-peso fine and two years of banishment, and they were also prohibited from living outside the Spanish enclosure. The content of these regulations was trumpeted 'in the usual places' of the city by the official town criers, then communicated to the governors and the councillors of the parcialidades as well as to the Franciscans, who were asked to translate the provisions into the vernacular language. Here, for example, is a report sent to the corregidor by a Franciscan from the San Sebastián parish:

I have not only retranscribed [the recommendations] into the Mexican language, I have also personally been through all the streets of my jurisdiction ... and have met numerous families who have asked me to indicate a parcel of land they can settle on ... I entreat you in turn to tell me which sites are suitable for settlement. ${ }^{41}$

This account shows the key role played by the administrators of the indigenous parishes: they were the fundamental points of relay between the highest authorities in the town and the Indian populations. They translated the ordinances from Castilian to Nahuatl, brought them to the attention of families, surveyed the vacant land for settlement and sent back written reports to the authorities describing the difficulties encountered in applying such a complex measure. Faced with mounting complaints from Indians unable to find a place to settle (as the areas on the periphery were already partly subdivided or occupied), the Audiencia assigned the Franciscans the task of mapping out the street paths and house blocks on the land to prepare for its future urbanization.

Our research has not yet allowed us to determine to what extent this measure was applied. We would need in particular to compare the parish registers of the Indian zones on different dates (before and after the provision) in order to check whether the displacement of the populations actually took place. But the persistence of the problem posed by the indigenous presence in the traza, stressed by numerous archival dossiers at later dates, proves that the exclusion of the Indians from the Spanish city was not fully realized.

41 AGN, Historia, vol. 413, fol. 61: 'No sólo hice copiar en el idioma mexicano, sino que salí en persona, por todas calles de esta ciudad donde se entendía mi jurisdicción ... y haber recurrido a mí muchas familias, pidiéndome les señale tierra donde habitar ... suplico me dé a mí lo que fuere servido, para señalar sitios para que ocupen los que los piden.' 
The revolt of 8 June 1692 is a privileged moment for analysing the crisis in urban law and order in the capital of New Spain. Two antagonistic conceptions of bad government - and by implication of good urban law and order - exploded on the evening of 8 June 1692. For the rioters, the priests of the indigenous parishes and certain members of the Audiencia, the mal gobierno was synonymous with tyranny, corruption and injustice: the viceroy and his clientele had upset the fragile equilibrium of a traditionally 'pactist' monarchy. Urban policing for them was above all a matter of urban management (the administration of the food supply, the exercise of justice, respect for freedoms and customs). For the authorities, the viceroy and the municipal government, the riot was the product of the uncivilized practices of the rabble, an uncouth and thieving plebeian class with deviant behaviours. The mal gobierno was for them about the behaviour of individuals and education. For these authorities, law and order in the city was in the first place synonymous with urbanity and good manners.

On another level, the riot sheds light on the actors who participated in the restoration of law and order in a city without armed forces. The king, the viceroy, the corregidor, the archbishop, the noble Spanish cavalry, the merchant militias, the governors of the parcialidades and the clerics all worked together to restore order in the capital. Whereas the city councillors played a minimal role and the corregidor was conspicuous in his absence, the Franciscans on the other hand played a fundamental role in this process. The uprising of 8 June 1692 testified to the fact that urban law and order was not based on a hierarchical system of law enforcement, repressive in nature and subordinate to the viceroy, but on a multitude of different entities and actors.

As for the means used, we can only underline the fact that there was nothing original in the measures taken: old formulas were applied (improvement of the supply system, use of the commercial militia as security forces, judicial repression) and extremely old legislation was revived. The restoration of the traza with the expulsion of the Indians and the recourse to the reduction model (the reducciones de indios) are the most flagrant examples. These ideas belonged to the earliest period of colonization. Some of the provisions, moreover, were not fully implemented, such as the prohibition of the sale of pulque or the banning of the Baratillo, which only lasted a few months. Finally, the only measures that were in any way innovative, such as the creation of the two cavalry units funded by the crown, did not last, as they were disbanded by royal decree in $1694 .{ }^{42}$ Ultimately, the riot of 8 June 1692 did not result in

42 The two cavalry units were terminated by royal decree in 1694 on the pretext that they represented an exorbitant cost for the royal tax office. AHDF, Historia en General, vol. 1, dossier 1 . 
the profound reform of the urban administration that might have been expected a priori. This traumatic event did not strike the authorities as an opportune moment to transform the law and order landscape, because any reform implied taking risks with potentially dangerous consequences. At the end of the seventeenth century, reaction prevailed in the capital of New Spain. 